\title{
Uppsala model: A contingent theory to explain the rise of EMNEs
}

\author{
Renan Henrique Oliveira ${ }^{1 \mathrm{~A}}$, Ariane Roder FigueiraA ${ }^{\mathrm{A}}$, and Monica Pinhanez ${ }^{\mathrm{B}}$ \\ ${ }^{A}$ Federal University of Rio de Janeiro, UFRJ/COPPEAD, Rio de Janeiro, RJ, Brazil \\ BINSPER Business School, São Paulo, SP, Brazil
}

\section{ARTICLE DETAILS}

\section{Article history:}

Received: 2 August 2017

Reviewed: 10 February 2018

Accepted: 7 April 2018

Available online: 1 May 2018

Double Blind Review System

\section{Scientific Editor}

Ilan Avrichir

\section{Keywords:}

Uppsala model

Emerging Market Multinationals (EMNEs)

Contingent Theory
ABSTRACT

The Uppsala model is the result of an intellectual journey where economic-type assumptions were purged and replaced by behavioral, network relationship, dynamic capabilities, effectuation, entrepreneurship and institutional theories, theories which seemed to explain better, the internationalization process in the current business environment. This conceptual paper illustrates how the Uppsala model evolved showing adaptions it went through and discuss whether the Uppsala model is contingent enough to explain the rise of EMNEs, a phenomenon that at first, puzzled international business scholars and questioned the validity of well-established stream of thoughts in the international business community.

(C) 2018 Internext | ESPM. All rights reserved!

\section{INTRODUCTION}

The Uppsala model also known as stage model is a milestone in the field of international business study as it breaks the hegemony of neoclassical assumptions that dominated the area. Johanson and Wiedersheim-Paul (1975) observed that Swedish companies internationalized as they were still comparatively small and that their operations abroad were gradually developed instead of large and spectacular foreign investments as postulated by textbooks of international business theories. Based, at first on the behavioral theory of the firm (Cyert e March, 1963; Aharoni, 1966) and Penrose (1959) theory of the growth of the firm and later on the network perspective adding elements from dynamic capabilities, effectuation and institutional approach the Uppsala model is characterized by an intellectual journey of detoxification from economics-type assumptions (Vahlne and Johanson, 2014). The Uppsala model inaugurated a behavioral approach in the field of international business.
On the behavior side, the Uppsala model is the most widely adopted approach among other stage models (Reid and Rosson, 1987) for comparisons of stage modals see Andersen (1993) and Bell (1995). On the economic side, the eclectic paradigm is the preeminent theoretical paradigm within International Business (Cantwell, Dunning, \& Lundan, 2010). Seeking to move away from the eclectic paradigm Vahlne and Johanson (2013) created an alternative model to the eclectic paradigm built on assumptions that according to them are realistic, relevant and based on theories and empirical researches that can explain control and coordination of the firm. So, in order to eliminate neoclassical assumptions and move focus from structure of production to change process in business relationship and entrepreneurship the multinational enterprises (MNEs) was named multinational business enterprises (MBEs).

The purpose of this paper is to understand whether after all this intellectual journey and 
reflection regarding the internationalization process the Uppsala model is contingent enough to explain the rise of emerging market multinational enterprises (EMNEs). The rise of EMNEs challenged mainstream theories and a fruitful debated regarding the need of new theories arose. Aharoni (2014) argue that international business theories reflect a reality, and if this reality changes the theory has to adapt in order to not become obsolete. According to him the international business theory did not predict the rise of EMNEs, hence, he concludes that an international business scholar has to develop a dynamic contingency theory of international business.

Application of the Uppsala model to EMNEs are rare (Meyer \& Thaijongrak, 2013), however, evidences from Ho-Fu Lau (1992), Zafarullan et al (1998), Elango and Pattnaik (2007, 2011) and Drauz (2012) show that knowledge, gradual learning and network relationship that are core assumptions of the Uppsala model are an important asset to explain the rise of EMNEs. Hence, this conceptual paper seeks to recover and analyses these critical perspectives present in the specialized literature regarding the Uppsala model capability to explain the rise of EMNEs. This conceptual paper does not intend to finish the debate with conclusive answers, its core intention aims at shedding light to lose ends of the Uppsala model and its apparent inability to explain the rise of EMNEs as identified by some international business researchers. In addition, this conceptual paper contributes in organizing the intellectual journey taken by the conceptualizers of the Uppsala model since its seminal work in 1977 until its last publication in 2014, though the core structure of the model remains the same, variables were removed and added through this journey in order to answer critics and adapt the theory to an ever-changing world.

Through its development trajectory the Uppsala model denies the eclectic paradigm and is challenged by the rise of EMNEs. This scientific battle finds supports in the work of Kuhn (1970) and Lakatos (1979). What is needed to become a paradigm? Does the addition of variables claimed alter the core theoretical assumptions? Adapt or die: are present paradigms doomed to die due to rapid changes in the contemporary world? To reflect about these questions, the thought of Kuhn (1970) regarding the bases of paradigm has supported the debate. Similarly, Lákatos (1979) provide reflections regarding competitions between research programs.
This paper is organized in 3 sections. The first part presents the foundations and drives of the Uppsala model. Section two presents the rise of EMNEs and empirical studies that used the Uppsala Model targeting companies form emerging economies. Finally, a conclusion, future research questions and limitations are presented.

\section{THE UPPSALA MODEL AND ITS CONTINGENT TRAJECTORY.}

Earlier on, the study of international business was a subject studied by international economists that dominated the field, and, therefore, the first attempts to develop a theory of international business were heavily framed by neoclassical assumptions (Rugman, Verbeke, \& Nguyen, 2011) and Western experiences of mature and large companies (Ramamurti, 2012). However, Johanson and Wiedersheim-Paul (1975) from the Uppsala University studied four Swedish companies - Sandvik, Atlas Copco, Facit and Volvo - and found empirical evidences that those firms started their international operation when they were comparatively small and followed a gradual development of their operations abroad rather than large, spectacular foreign investments. Hence, based on the behavioral theory of the firm (Cyert e March, 1963; Aharoni, 1966) and Penrose (1959) theory of the growth of the firm Johanson and Vahlne (1977) created the Uppsala model. The model assumes that the motivation to internationalize rises after domestic expansion to develop new markets and opportunities abroad. The process of internationalization is done cautiously in order to avoid uncertainties, gather knowledge and resources needed, therefore, four incremental stepwise extensions called establishment chain is proposed: (1) no regular export activities (2) export via independent representativeness (agent) (3) sales subsidiary (4) production - manufacturing. The psychic distance between home and host country is an important asset as it can prevent or disturb the flow of information between the supplier and customer (Hörnelll, Vahlne, \& Wiedersheim-Paul, 1972), it can also affect learning and understanding of a foreign environment (Nordstrom \& Vahlne, 1994) and be the source of uncertainties as a result of cultural differences (O'Gray \& Lane, 1996).

The world changed since the first release of the Uppsala model in 1977. Global competition and the development of new technologies made companies internationalize faster than before (Johanson \& 
Vahlne, 2003). Studies focusing on international new ventures and born globals (Oviatt \& McDougall, 1994; Madsen \& Servais, 1997), high technology based firms (Autio, Sapienza, \& Almeida, 2000) services (Coviello \& Munro, 1997; Majkgård \& Sharma, 1998) small business firms (Chetty \& Blankenburg, 2000) and on the emerging market multinational enterprise (Mathews, 2006) claimed for new models of internationalization to explain the new business environment.

However, as networks and networks relationships were a common point in many researchers (Oviatt and McDougall, 1994; Bell, 1995; Coviello and Munro, 1997; Chetty and Blankenburg Holm, 2000) and as there were still evidences that the old behavioral models of internationalization and its concepts were still accurate, and showed that experiential knowledge become an important concept in internationalization (Kogut \& Singh, 1988; Erramilli, 1991; Chang, 1995; Barkema, Bell, \& Pennings, 1996; Eriksson, Johanson, Majkgard, \& Sharma, 1998; Delios \& Beamish, 2000 Luo \& Peng, 1999) Johanson and Vahlne (2003) decided to integrate the two approaches creating a network-based model of internationalization.

The network-based model o internationalization is not an adaption of the previous one, it brings some remarkable changes. Johanson and Vahlne (2009) rejected the assumption that country market economic, institutional and cultural differences are obstacles to foreign entry markets, hence, the psychic distance as a source of uncertainty and the established chain become less relevant. The main source of uncertainty is regarding the liability of outsidership (Johanson \& Vahlne, 2009). Companies that do not belong to a relevant network are outsiders and suffers from the liability of outsidership and foreigness, it is assumed that foreigness is an obstacle in the process of becoming an insider and to the process of internationalization. Therefore, interactions among companies in the insidership of relevant networks are an essential asset for learning, build mutual trust and reciprocal knowledge and commitment that are preconditions for internationalization (Ford, 1979, 2002; Johanson \& Vahlne, 2009, 1990 Vahlne; Vahlne \& Johanson, 2002).

Another important aspect argued by Johanson \& Vahlne (2009) is that the "effectuation process" developed by Sarasvathy (2001) is fully consist with the network-based model of internationalization. This happens due to similarities such as incremental development and high degree of uncertainty faced by both the entrepreneur when launching a new business and the internationalization process that is based in the entrepreneur's existing network (Johanson \& Vahlne 2003). Thus, in the networkbased model the entrepreneurship has a major role in the process of internationalization.

Vahlne and Johanson (2013) then conclude that the Uppsala model has to be very general in nature and be able to welcome different theories within the International Business study such as location, mode operation and strategic change in order to be an alternative to the eclectic paradigm and as the MBE develops its own "individual personality" (Vahlne \& Johanson, 2013) or "institutionally related advantages" (Dunning \& Lundan, 2008) the contextual aspects cannot be forgotten. In a later paper reflecting about their intellectual growth and maturity Vahlne and Johanson (2014) argue that their research is a gradual denial and substitution of neoclassical assumptions with ones derived from the behavioral and network theory which they have strongly relied to build and develop the Uppsala model - now finally called a theory. The new version of the model is interested in how the multinational business enterprise continue to evolve, therefore, consistent with the question suggested by Peng, Wang, \& Jiang (2008, p. 931) "what determines the success or failure of firms around the globe? Though the model includes performance (Vahlne and Johanson, 2014) it is focused more on "trying" rather than "succeeding" as argued by Winter (2012). The term multinational business enterprise (MBE) is used in the same conditions as already mentioned. Table 1 the Uppsala intellectual journey.

The next thought regarding the Uppsala model was released in 2017 (Figure 1). Vahlne and Johanson (2017) present "a general model of the evolution of the multinational business enterprise (MBE) from early steps abroad to being a global firm" (p. 1087). Capability-creation process is included in the model as it is the reason of internationalization, efficient governance and economies of scale

The structure and general content of the model still the same as the original model developed in 1977: state and change variables. Change variables are highly important as it is where action takes place. Knowledge development process, that is, learning, 
Tab.1

Changes in the Uppsala Model

\begin{tabular}{|c|c|c|c|}
\hline $\begin{array}{c}\text { The Basic Mechanism of } \\
\text { Internationalization } \\
\text { (1977) }\end{array}$ & $\begin{array}{l}\text { The business Network } \\
\text { Internationalization } \\
\text { Process Model (2009) }\end{array}$ & $\begin{array}{c}\text { The Uppsala } \\
\text { Model of MBE Evolution } \\
\text { (2013) }\end{array}$ & $\begin{array}{l}\text { The structure of the Uppsala } \\
\text { Model of MBE Evolution } \\
\text { (2014) }\end{array}$ \\
\hline $\begin{array}{l}\text { (1) Motivation to } \\
\text { Internationalization after } \\
\text { domestic expansion (2) } \\
\text { Internationalization Process is } \\
\text { done caustiously to avoid: } \\
\text { uncertainty, acquire knoledge } \\
\text { and resources ( } 3 \text { ) The } \\
\text { established chain is followed: no } \\
\text { regular export activities; export } \\
\text { via independent agend; sales } \\
\text { subsidiary; production } \\
\text { manufacturing (4) Commitment } \\
\text { increases as the company } \\
\text { advances in the established due } \\
\text { to market experience and } \\
\text { information (5) Psychic Distance } \\
\text { is considered in the first } \\
\text { international Business } \\
\text { movement }\end{array}$ & $\begin{array}{l}\text { (1) Psychic Distance become } \\
\text { irrelevant as country market } \\
\text { economic, institutional and } \\
\text { cultural differences are rejected } \\
\text { (2) The mains source of } \\
\text { uncertainty is due to the liability } \\
\text { of outsidership (out of an } \\
\text { important network) (3) Liability } \\
\text { of foreigness is an obstacle in the } \\
\text { process of internationalization } \\
\text { (4) Interactions with insiders } \\
\text { (menbers of a network) provides } \\
\text { learning, trustship, reciprocal } \\
\text { knowledge and commitment that } \\
\text { are key feature of } \\
\text { internationalization (5) } \\
\text { Effectuation process is consistent } \\
\text { with the network model (6) } \\
\text { Entrepreneurship plays an } \\
\text { important role in the process of } \\
\text { internationalization (7) The } \\
\text { internationalization process can } \\
\text { be done in three ways: business } \\
\text { with a company overseas; an } \\
\text { intermediary firm overseas can } \\
\text { trigger the process and a partner } \\
\text { pulls up a company overseas }\end{array}$ & $\begin{array}{l}\text { (1) Prosperous firms get } \\
\text { opertional and dynamic } \\
\text { capability advantages (2) } \\
\text { Companies are boundly rational } \\
\text { and network dependence is a key } \\
\text { role to internationalize (3)The } \\
\text { environment is considered, trust, } \\
\text { cost and profitability is } \\
\text { considered (4) TCE is not able to } \\
\text { judge managerial experiences (5) } \\
\text { limited number of actors in the } \\
\text { market dealing with } \\
\text { heterogenous and products and } \\
\text { services (6) Companies adjust to } \\
\text { each other to improve efficience } \\
\text { (7) Markets are networks of } \\
\text { interconnecte relationships (8) } \\
\text { Insidership is a source of } \\
\text { resources important to the } \\
\text { internationalization process (9) } \\
\text { market network develops from } \\
\text { the interaction between market } \\
\text { and actors (10) Market is in } \\
\text { constnat change (11) MNE is } \\
\text { considered a network itself (12) } \\
\text { Value is created through build, } \\
\text { developement and coordination } \\
\text { of business network relationship }\end{array}$ & $\begin{array}{l}\text { (1) The Uppsala Model is a } \\
\text { gradual substitution of } \\
\text { economics-type assumptions } \\
\text { with ones derived from the } \\
\text { behaviral theory (2) The Uppsala } \\
\text { model is na alternative to } \\
\text { transaction-cost economics (3) } \\
\text { The entrepreneur itself can be a } \\
\text { source of firm specific advantage } \\
\text { (4) The MBE is understood as a } \\
\text { network of semi independet } \\
\text { units (5) The Uppsala Model is } \\
\text { compatibel with the "next big IB } \\
\text { question": What determies the } \\
\text { success or failure of firms around } \\
\text { the globe? (6) The model } \\
\text { concentrates on trying rather } \\
\text { than suceeding (7) Companies } \\
\text { compete with each other and } \\
\text { with networks }\end{array}$ \\
\hline
\end{tabular}

Source: made by the authors

creating, and trust-building, are occurring continuously, thereby changing the state variables. An example is that learning assumes that an existing capability can be improved upon, at least if the learning affects the resource commitment process, which means in turn that the state of the firm's reservoir of capability is being altered (p.1092) Vahlne and Johanson (2017) add that a decision to reconfigure resources affects not only capabilities, but also the actual resource positions of both the firm and any network partner, and subsequently performance. At the same time, a new resource position may be a reflection of reduced commitment, or of de-commitment, such as reducing diversification, leaving a market, and discontinuing a relationship. A changed capability and resource position will in turn affect further knowledge development and decision making or resource allocation. (1092).

Hence, Vahlne and Johanson (2017) no longer consider the mode of operation (stablished chain) in a foreigner market to be a valid measure of the degree of commitment.

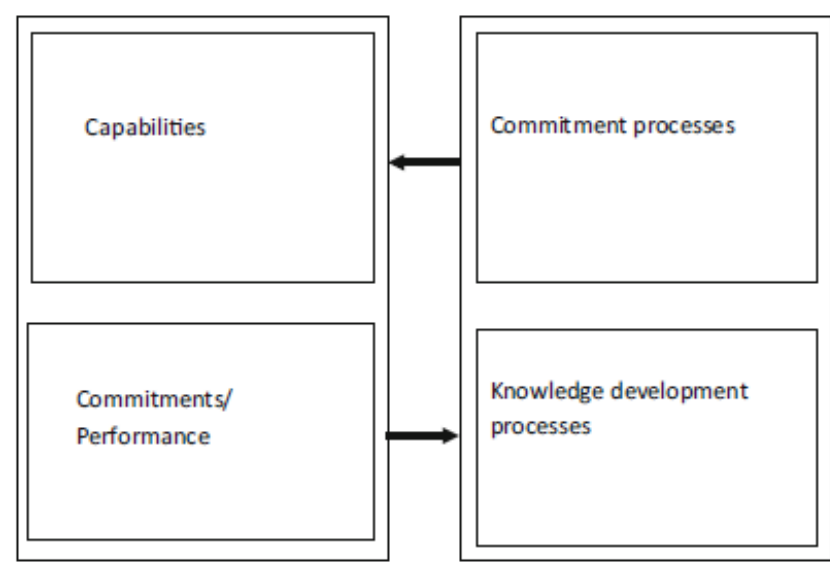

Fig. 2

Uppsala Model (Vahlne and Johanson, 2017).

Commitment process and knowledge development process are considered change variables. The former, implies reconfiguration and coordination that faces risk, uncertainty and partial ignorance. When 
capabilities and relationships change, and the performance level are gained new knowledge is developed through learning, creating and trust building. This new knowledge is converted into commitment process to reconfigure resources and to coordinate action. The latter argues that the knowledge development process of learning, creating and trust-building is done either inter- or intraorganizational process and that is because the firm is understood as a network itself (Johanson and Vahlne, 2009).

Capability (operational and dynamic) and commitment-performance are state variables and are the result and effect of change variable. Capabilities reflects the ability to use resources for a particular purpose. Operational capability refers to firm specific advantage (FSA) - implicitly included in earlier versions of the Uppsala model - such as privileged access to raw materials, brand, technology advantages associated with multinationality itself such as superior governance systems and the management skills to operate an internal, multinational network. Dynamic capability, on the other hand, is an ability to "integrate, build and reconfigure internal and external competencies to address rapidly changing environments" (Teece, 2014: 16). This capability is built inside of the firm through repetition and cannot be bought. Commitments illustrates how resources are dispersed over the MNE's functions, its product lines, the countries where it is active and the relationships in which it has invested. Performance, on the other hand, refers to what has already been achieved. According to Vahlne and Johanson (2017) both connotations are present simultaneously and both connotations determine the scope and content of the knowledge development process.

\section{THE RISE OF THE EMERGING MARKET MULTINATIONAL ENTERPRISES (EMNES)}

Change of ideology and political environmental in the late 1970s and early 1980s provided the right elements to the rise of the Emergent Market Multinational Enterprise (EMNEs). Nowadays, developing economies lead the FDI global flow and reached its highest level at $\$ 681$ billion with a 2 per cent rise and nine of the 20 largest investor countries were from developing or transition economies (UNCTAD, 2015). The raise of EMNE brought some questions: were the mainstream theories wrong? EMNEs have competitive advantage? If so, what are they? How different is the internationalization process of these firm? Does ownership matter and, if so, how (Aharoni, 2014, p.15). Ramamurti (2012) reflected on why developing economies facing technological and economic backwardness are able to produce MNEs at al. as poor countries, it is more reasonable to think that those countries are more prone to import capital rather than export it. However, Ramamurti (2009a, 2009) argues that international business scholars have been deceived by traditional assumptions of what produces multinationals and that they are not able to see that EMNEs do have advantages that are different from multinationals of developed countries. According to Williamson (2015) this non-traditional advantages are already acknowledged in the literature. Williamson and Zeng (2009) highlights the ability EMENs have to innovate in cost. Prahalad (2006) discussion economic opportunities at the bottom of the pyramid argue that EMENs efficiently create demand for non-traditional segments of society. Morck, Yueng and Zhao (2008) and Cuervo-Cazurra and Genc (2008) argue that at home EMNEs operate in an environment with weak institutions and lack of unfractured, the ability to deal with such environment give them an advantage compared to traditional multinationals when internationalizing to similar environment, as the latter, is used to work in a business environment with strong institutions and good infrastructure. For Williamson (2015) EMNEs have to compete in the global market on three interrelated potential sources of competitive advantage: innovation, international value chain configuration and foreign mergers and acquisitions. For innovation it was found little evidence that EMNEs have reached the technological frontier, however, there are evidences showing that they build capability to innovate. In the value chain configuration (VCC) EMNEs choose different strategies. For example, Brazilian companies internationalize downstream operations in order to improve the international market to Brazilian products. Regarding merge and acquisition the study argue that this movement was primarily have access to resources and knowledge but also to enhance its competitive advantage and speed up its internationalization process.

Therefore, the rise of EMNEs triggered a debate regarding the capability of main stream theories explain this phenomenon. Aharoni (2014) argue that international business theories cannot be universal as 
in exact sciences, they represent a certain reality, in case the phenomenon observed changes the theory has also to change and be adapted. He continues saying that in a world that is constantly changing theories that were once strong and robust can become obsolete. Cuervo-Cazurra (2012) organize this debate as being: hot (a new theory is required), cold (no need for a new theory) or just right (existing theories can be extended).

In the hot debate Mathews (2006) advocates the need of a new theory as the main stream theories were developed in advanced economies. On the cold side Dunning, Kim and Park (2008) and Rugman (2010) argue that this phenomenon can be explained with existing theories. For the former the apparent differences in the internationalization trajectory can be explained by improvements of operations since 1960s and that globalization has sped up this process, the latter argues that the firm and country specific advantage explain the rise of EMNEs, moreover, Casson (2015) state that Rugman rejected theoretical pluralism as many international business theories were weak and confused. Yet according to Casson (2016) for Rugman the internalization theory was the holy grail in the international business. On the just right side Ramamurti (2009) argues that even though, the environmental characteristics influences the path of internationalization, it is not enough to refute all predictions of existing theories. For example, CuervoCazurra (2008) studied EMNEs from Latin America (Multilatinas) and suggests that the Uppsala Model needs further extension as the business environment context of Multilatinas is different from those of developing regions. In a latter study Cuervo-Cazurra (2012) offers two potential theoretical extensions to the Uppsala model from the analysis of EMNEs: (1) "separate psychic distance from market attractiveness in the selection of countries (2) Managers have levels of risk aversion influenced by home country that affect country selection and entry mode selection" (Cuervo-Cazurra, 2012, p. 159).

Despite the on-going debate, attempts to convincily explain the rise of EMNEs and the critics the Uppsala model have faced, there is still an urgent need for more empirical studies in order to provide a better picture of the elements surrounding this phenomenon. According to Meyer and Thaijongrak (2013) the application of the Uppsala model to EMNEs are rare. Luo and Zhang (2016) corroborates with this trend, in a qualitative content analysis, 166 articles from 11 mainstream international business and management journals published during 19902014 were systematic reviewed to uncover what is known regarding EMNEs, it was found that only 8 articles adopted the Uppsala model. According to them the institutional theory, resource-based view, the eclectic paradigm, springboard perspective and organizational learning are the most five used paradigms to study the rise of EMNEs. However, the Uppsala model has not been the most used paradigm it envelopes institutional theory and organizational learning showing its generality and contingent characteristic

\subsection{Random Empirical Studies of EMNEs and the Uppsala Model.}

The studies shown below were sourced from the literature and from random search that popped in. It has no intention to be any kind of literature review nor to end the debate but to be examples of how the Uppsala model is being applied to EMNEs. Elango and Pattnaik (2007), studied 794 companies from India to understand how these EMNEs build capabilities to operate in international markets, they found that the Uppsala model and network models on internationalization are able to explain how EMNEs build capabilities for international operations. In another study Elango and Pattnaik (2011) looked into a sample of 175 acquisitions by Indian companies during 2000-2006 and founded evidence that support the spring board perspective (Luo and Tung, 2007) which state that acquisitions are strategically used to minimize risk, optimize their ability to learn and build capability. Elango and Pattnaik (2011) also argue that the core promise of the Uppsala model of learning is valid, however two adaptions are needed. First, the development of knowledge in an incremental manner is not an option for EMNEs due their current competitive necessities. Second, the argument of moving according to the psychic distance is reasonable for advanced countries. It is not clear whether leaning acquired from other EMNEs can be transferred to advanced nations or even be effectively used in local market to compete with international rivals. Investigating small-scale enterprises from Pakistan - an emerging economy Zafarullah et al., (1998) found little support for the stage model, although, the network perspective found to be relevant in all aspects of internationalization. Table 2 illustrates the application of the Uppsala model theory to EMNEs. Drauz (2012) studied the factors and the process of internationalization of 12 Chinese automobile 
Tab. 2

Application of the Uppsala Model (UM) to EMNEs

\begin{tabular}{|c|c|c|c|c|c|}
\hline Source & Authors & $\begin{array}{l}\text { Support } \\
\text { the } \\
\text { UM }\end{array}$ & $\begin{array}{l}\text { Elements } \\
\text { of the } \\
\text { UM are } \\
\text { Found }\end{array}$ & $\begin{array}{l}\text { Do not } \\
\text { support } \\
\text { the UM }\end{array}$ & Arguments \\
\hline $\begin{array}{l}\text { Meyer and } \\
\text { Thaijongrak } \\
\text { (2013) }\end{array}$ & $\begin{array}{l}\text { Elango and } \\
\text { Pattnaik } \\
(2007)\end{array}$ & $x$ & & & $\begin{array}{l}\text { The Uppsala and network models of internationalization serve as an } \\
\text { ideal conceptual framework to understand how EMNEs build } \\
\text { capabilities for international operations ( } p .544)\end{array}$ \\
\hline $\begin{array}{l}\text { Meyer and } \\
\text { Thaijongrak } \\
\text { (2013) }\end{array}$ & $\begin{array}{l}\text { Elango and } \\
\text { Pattnaik } \\
(2011)\end{array}$ & & $x$ & & $\begin{array}{l}\text { It was found evidences from Indian companies that support the spring } \\
\text { board perspective. However, knowledge that is the core promise of } \\
\text { the Uppsala Model is valid with two adaptations: (1) The development } \\
\text { of knowledge is not an option due their competitive necessities (2) the } \\
\text { psychic distance is reasonable only for advanced countries }\end{array}$ \\
\hline $\begin{array}{l}\text { Coviello and } \\
\text { McAuley } \\
\text { (1999) }\end{array}$ & $\begin{array}{l}\text { Zafarullah et } \\
\qquad \begin{array}{l}\text { al } \\
(1998)\end{array}\end{array}$ & & $x$ & & $\begin{array}{l}\text { In studying small scale enterprises from Pakistan it was found little } \\
\text { support for the stage model, } \\
\text { however the network perspective found to be important in all aspects } \\
\text { of internationalization }\end{array}$ \\
\hline Randon searh & $\begin{array}{c}\text { Drauz } \\
(2012)\end{array}$ & & $x$ & & $\begin{array}{l}\text { In his study it was found that some automobile manufacturers from } \\
\text { China are aligned with the Uppsala model premises, nevertheless it is } \\
\text { concluded that the internationalization of Chinese automobile cannot } \\
\text { be explained by one theoretical model only. }\end{array}$ \\
\hline $\begin{array}{l}\text { Coviello and } \\
\text { McAuley } \\
\text { (1999) }\end{array}$ & $\begin{array}{l}\text { Ho-Fu Lau } \\
\text { (1992) }\end{array}$ & & $x$ & & $\begin{array}{l}\text { Garments manufactures from Hong Kong internationalize differently } \\
\text { from those in US and EU as they are foreign market-oriented. } \\
\text { However, it is assumed that the process of internalization is } \\
\text { incremental and the psychic distance is important considering far } \\
\text { away markets as knowledge is accumulated }\end{array}$ \\
\hline $\begin{array}{l}\text { Randon } \\
\text { search }\end{array}$ & $\begin{array}{l}\text { da Rocha } \\
\text { and da Silva } \\
\text { (2009) }\end{array}$ & & & $x$ & $\begin{array}{l}\text { Brazilian companies do not follow the established chain due to their } \\
\text { low level of export intensity }\end{array}$ \\
\hline
\end{tabular}

Source: Made by the authors

manufactures. Even though some of the companies were aligned with the assumption of the Uppsala model, the stage process, and the network perspective jointly, the study concluded that the internationalization of Chinese automobile companies cannot be explained by one theoretical model alone. Ho-Fu Lau (1992) studying the internationalization process of garment manufactures in Hong Kong, found that their process of internationalization differed from those of North America and Western Europe as they were foreign market-oriented at birth due to local market size. Nevertheless, the Hong Kong garment manufacturers showed also a process of incremental commitment driven by the psychological distance and only when knowledge is accumulated far markets are considered. In the case of Brazilian companies, (da Rocha \& da Silva, 2009) argue that they do not develop the establishment chain due to their low level of export intensity (Markwald, 2001). Therefore, Brazilian companies have little or any interest to commit with their sales abroad (Iglesias \& Motta Veiga, 2002), an argument corroborated by (VeronWortzel, Wortzel, \& Deng, 1988), companies are content in reaching the third stage (export via sales subsidiary) as the next step requires capabilities they do not possess. In this case Brazilian companies do not feet the model due to lack of development of the established chain or disruptions at certain point.

\section{DISCUSSION AND FINAL CONSIDERATIONS}

The development of the Uppsala model is an intellectual journey of a gradual replacement of economics-type assumptions in a clear dispute of competitive research programs (Lakatos, 1979), to assumption of behavioral, network, dynamic capabilities, "effectuation" and institutional approaches, that in order to change focus from structure of production to change process in business relations and entrepreneurship replaced the anachronism MNE to MBE. Kuhn (1970) argues that a new paradigm is the result of a revolution, science in 
this sense is not a process of knowledge accumulation of the old paradigm. Science evolves when anomalies are found in an instrument or theory that is used to explain a phenomenon. The Uppsala model itself is an anomaly. It found that Sweden companies behavior differently from USA large companies when internationalizing and asserted that neo-economic assumptions where too vague. These empirical observations triggered a new school of international business that influenced researchers all over the world. The intriguing question now is whether the rise of EMNEs represents an anomaly or is just a new puzzle to be solved by international business researchers. Hence, this conceptual paper attempts to understand, how this intellectual journey can contribute to explain the rise of the EMNEs. A shown above the application of the Uppsala model to EMNEs are rare (Meyer \& Thaijongrak, 2013), however, a closer look at table 2, can provide some fruitful thoughts.

Elango and Pattnaik $(2007,2011)$ argue that the Uppsala model and network models fully explain how EMNEs build up capabilities to initiate their internationalization process but are not able to explain the acquisition process. What insights these two studies from the same authors with different results provide? Given that the Uppsala model and network models are better to explain building capability and the springboard perspective to explain acquisitions, do EMNEs need a new, hybrid theory? Is the Uppsala model contingent and broad enough to envelope the rise of EMNEs? Is the framework for analyzing the role of foreign acquisitions in the internationalization process offered by Andersson et al., (1997) robust enough? Do EMNEs from other regions follow the same pattern? Certainly, more studies are need in this direction. da Rocha and da Silva (2009) argue that the EMNEs do not follow the establishment chain, however to be fair, Johanson and Wiedersheim-Paul (1975) argue that the establishment chain is not always expected to occur following the four stages, that's because not all markets are large enough and firm with extensive experience can leapfrog stages (p. 307), hence, this critic is not valid and should be reviewed.

However, an important empirical evidence found from the studies analyzed on table 2 is that knowledge, gradual experiential, learning and network relationship that are core premises of the Uppsala model seem to be an important asset to explain the rise of EMNE. Here is the point where this research deviates from others. To the best of our knowledge, no other study has illustrated that from a sample of studies analyzing EMNEs the core assumptions of the Uppsala Model would be important assets in their internationalization process. Hence, we ask: Is the Uppsala model able to explain the rise of the EMNEs? As the core assumptions of the Uppsala model are important to the internationalization process of EMNEs this conceptual paper suggests that the Uppsala model is strong, solid and a contingent theory able and robust enough to solve the puzzle of the EMNEs, now labelled as emerging market multinational business enterprise (EMMBE) to illustrate that multinationals from emerging economies are aligned with the core premises of the Uppsala model. One last comment, Vahlne and Johanson (2013) argue that the apparatus of the Uppsala model is sufficient general to be used in managerial process that are characterized by uncertainty, ambiguity and complexity, such acquisition (Andersson, Johanson, \& Vahlne, 1997) globalization (Vahlne, Ivarsson, \& Johanson, 2011) Headquarter management (Vahlne, Schweizer, \& Johanson, 2012) and coordination of networks (Vahlne \& Johanson, 2013). If the model is so general, why would it be unable to explain the rise of EMNEs and then be considered a contingent theory?

The limitation of this conceptual paper is the limited number of studies analyzed applying the Uppsala Model to EMNEs. Future empirical research is needed in this direction to corroborate with conclusions derived from the available literature. The paradigm dispute between mainstream theories and the new growing trend such as the spring board perspective to explain the rise of EMNEs also need attention as it helps leveraging our understanding and is an opportunity to see science unfolding and being enhanced before our eye.

\section{REFERENCES}

- $\quad$ Aharoni , Y. (1966). The foreigner Investment decision process. Boston: Havard Business School Press.

- $\quad$ Aharoni, Y. (2014). To understand EMNEs a dynamic IB contingency theory is called for. International Journal of Emerging Market, 377-385.

- Andersen, O. (1993). On the internationalization process of firms: a critical analysis. JIBS, 209-231.

- Andersson, U., Johanson, J., \& Vahlne, J.-E. (1997). Organic Acquisitions in the Internationalization Process of the Business Firm. Management International Review, 67-84. 
- Augier, M., Kreiner, K., \& March, J. G. (2000). Introduction: some roots and branches of organizational economics. Special issue of Industrial and Corporate Change, 555-565.

- Autio, E., Sapienza, H. J., \& Almeida, J. G. (2000). Effects of age entry, knowledge intensity, imitability on international growth . Academy of Management journal, 909-924.

- Barkema, H. G., Bell, J. H., \& Pennings, J. M. (1996). Foreign Entry, Cultural Barriers and Learning. Strategic Management Journal, 151-166.

- Bartlett, C. A., \& Ghoshal, S. (1989). Managing Across Borders. The Transnational Solution. Boston: Harvard Business School Press.

- Bell, L. (1995). The internationalization of small computer software firms: a further challenge to "stage" theories. European Journal of Marketing, 60-75.

- Cantwell, J. A., Dunning, J. H., \& Lundan, S. M. (2010). An evolutionary approach to understanding international business activity: The co-evolution of MNEs and the institutional environment. Journal of International Business Study, 41-44.

- Casson, M. (2016). (in press) Alan Rugman's methodology. International Business Review.

- Chang, S. J. (1995). International Expansion Strategy of Japanese Firms: Capability Building Through Sequential Entry. Academy of Management Journal, 383-407.

- $\quad$ Chetty, S., \& Blankenburg, D. H. (2000). Internationalization of Small to Medium-Sized Manufacturing Firms: An Network Approach . International Business Review, 77-93.

- Cohen, M. D., \& Bacdayan, P. (1994). Organizational routines are stored as procedural memory? Organization Science, 554-568.

- Cohen, W. M., \& Levinthal, D. A. (1990). Absorptive capacity: a new perspective on learning and innovation. Administrative Science Quarterly, 128-152.

- Cook, K. S., \& Emerson, R. M. (1978). Power equity and commitment in exchange networks. American Sociological Review, 721-738.

- Coviello, N. E. (2006). The network dynamics of international new ventures. Journal of International Business, 713-731.

- Coviello, N., \& Munro, H. (1997). Network relationships and the internationalization process of small software firms. International business review, 361-386.

- Cuervo-Cazurra, A. (2008). the Multinationalization of Developing Country MNEs: The case of Multilatinas. Journal of International Management, pp. 138-154.

- Cuervo-Cazurra, A. (2012). Extending Theory by Analyzing Developing Country Multinational Companies: Solving the Goldilocks Debate. Global Strategy Journal, 153-167.
- Cuervo-Cazurra, A., \& Genc, M. (2008). Transforming Disadvantages into Advantages: Developing country MNEs in the least developed countries. Journal of International Business, 957-979.

- Cyert, R., \& March, J. (1963). The behavioral theory of the firm. Englewood Cliffs: Prentice-Hall.

- da Rocha, A., \& da Silva, J. F. (2009). The internationalization of Brazilian Firms: An Introduction to the Special Issue. Latin American Business Review, 61-71.

- Delios, A., \& Beamish, P. W. (2000). Ownership Strategy of Japanese Firms: Transactional, Institutional and Experience Influences. Strategic Management Journal , 915-930.

- Drauz, R. (2012). In Search of a Chinese internationalization theory: A study of 12 automobile manufacturers. Chinese Management Studies, 281-309.

- Dunning, J. H. (1988). The Eclectic Paradigm of International Production: A restatement and some Possible Extensions. Journal of International Business Studies.

- Dunning, J. H., \& Lundan, S. M. (2008). Multinational Enterprises and the Global, Economy. Cheltenham: Edward Elgar.

- Dunning, J., Kim, C., \& Park, D. (2008). Old Wine in new Bottles: a comparison of emerging-market TNCs today and developed country TNCs thirty years ago. In K. Sauvant, The rise of transnational corporations from emerging Markets: Threat or Opportunity? (pp. 158179). Cheltenham: Edward Elgar.

- Elango, B., \& Pattnaik, C. (2007). Building capabilities for international operations through networks: a study of Indian firms. Journal of International Business Studies, 541-555.

- Elango, B., \& Pattnaik, C. (2011). Learning Before Making the Big Leap: Acquisition Strategies of Emerging Market Firms. Management International Review, 461481.

- $\quad$ Ellis, P. D. (2000). Social ties and foreign market entry. Journal of international Business, 443-469.

- Eriksson, K., Johanson, J., Majkgard, A., \& Sharma, D. D. (1997). Experiential Knowledge and Cost in the Internationalization Process. Journal of International Business, 337-360.

- Erramilli, M. K. (1991). The Experience Factor in Foreign Market Entry Behavior of Services. Journal of International Business Studies, 479-501.

- $\quad$ Ford, D. (1979). Developing Buyer-Seller Relationships in Export Marketing. Organization, Marknad och Samhälle, 291-307.

- Ford, D. (2002). Understanding Business Marketing and Purchasing. London: Thompson Learning.

- Forsgren, M., Holm, U., \& Johanson, J. (2005). Managing the Embedded Multinational: A Business Network View. Cheltenham: Edward Elgar. 
- Ghosal, S., \& Moran, P. (1996). Bad for practice: a critique of the transaction cost theory. Academy of Management Review, 481-510.

- Ghoshal, S., \& Bartlett, C. A. (1990). The multinational corporation as an interorganizational network . Academy of Management Review, 603-625.

- Helfat, C. E., Finkelstein, S., Mitchell, W., Peteraf, M. A., Singh, H., Teece, D. J., \& Winter, S. G. (2007). Dynamic capabilities. Understanding Strategic Change in Organizations. Malden: Blackwell.

- Ho-Fu Lau. (1992). Internationalization, Internalization, or a New Theory for Small, Low-technology Multinational Enterprise? European Journal of Marketing, 17-31.

- Hörnelll, E., Vahlne, J.-E., \& Wiedersheim-Paul, F. (1972). Exports and Foreign establishments. Uppsala: ALmqvist \& Wiksell.

- Hymer, S. (1960/1976). The international operations of national firms: a study of direct foreign investment. Cambridge: MIT Press.

- Iglesias, R. M., \& Motta Veiga, P. (2002). Promoção da Exportação via Internacionalização das Firmas de Capital Brasileiro. In A. C. Pinheiro, R. Markwald, \& L. V. Pereira, O Desafio das Exportações (pp. 367-446). Rio de Janeiro: BNDES.

- Johanson, J., \& Mattson, L.-G. (1988). Internalization in Industrial System - a Network Approch. In N. Hood, \& J. Vahlne, Strategies in Global Competition (pp. 287-314). New York: Croom Helm.

- Johanson, J., \& Vahlne, J.-E. (1977). The Internalization Process of the Firm - A Model of Knowledge Development and Increasing Foreign Market Commitments. Journal of International Business Studies, pp. 23-32.

- Johanson, J., \& Vahlne, J.-E. (1990). The Mechanism of Internationalization. International Marketing Review, pp. 11-24.

- Johanson, J., \& Vahlne, J.-E. (2003). Business Relationship Learning and Commitment in the Internationalization Process. Journal of International Entrepreneurship, 83-101.

- Johanson, J., \& Vahlne, J.-E. (2006). Commitment and Opportunity development in the Internationalization Process: A Note on teh Uppsala Internationalization Process Model. Management International Review, 165-178.

- Johanson, J., \& Vahlne, J.-E. (2009). The Uppsala Internationalization Process Model Revisited: From Liability of Foreigness to Liability of Outsidership. Journal of International Business Studies, 1411-1431.

- Johanson, J., \& Wiedersheim-Paul, F. (1975). The Internationalization of the Firm - Four Swedish Cases. The Journal of Management Studies, pp. 305-322.

- Kirzner, I. M. (1973). Competition and Entrepreneurship. Chicago: Chicago University Press.
- Kogut, B. (2000). The network as knowledge: generative rules and the emergence of structure. Strategic Management Journal , 405-425.

- $\quad$ Kogut, B., \& Singh, H. (1988). The Effect of National Cultures on the Choice of Entry Mode. Journal of International Business Studies, 411-432.

- Kuada, J., \& Sorensen, O. J. (2000). Internationalization of Companies from Developing Countries. New York: International Business Press.

- Kuhn, T. S. (1970). The Structure of Scientific Revolutions. Chicago: The University of Chicago Press.

- Lakatos, I. (1979). O falseamento e a metodologia dos programas de pesquisa científica. In I. Lakatos, \& A. Musgrave, A crítica e o desenvolvimento do conhecimento. São Paulo: Cultrix.

- Luo, Y., \& Peng, M. (1999). Learning to compete in a transition economy: experience, environmentand performance. Journal of Internation Business Studies, 269-295.

- Luo, Y., \& Tung, R. (2007). international Expansion of Emerging market enterprises: A springboard perspective. Journal of international Business Studies, pp. 481-498.

- Luo, Y., \& Zhang, H. (2016). Emerging Market MNEs: Qualitative Review and Theoretical Directions. Journal of International Management, 1-18.

- Madsen, T. K., \& Servais, P. (1997). The internationalization of Born Globals: An Envolutionary Process? International business Review, 561-583.

- Majkgård, A., \& Sharma, D. D. (1998). Client-following and market-seeking strategies in the internationalization of service firms. ournal of Businessto-Business Marketing, 1-41.

- Markwald, R. (2001). O Impacto da Abertura Comercial sobre a Indústria Brasileira: Balanço de uma Década. Revista Brasileira de Comércio Exterior, 7-36.

- Mathews, J. (2006). Dragon Multinationals: New Players in 21st Century globalization. Asia Pacific J Management, pp. 5-27.

- Meyer, K., \& Thaijongrak, O. (2013). The dynamics of emerging economy MNEs: how the internationalization process model can guide future research. Asia Pac J Manag, 1125-1153.

- Morck, R., Yueng, B., \& Zhao, M. (2008). Perspectives on China's outward foreign direct investments. Journal of Internationa Business Studies, 337-350.

- Morgan, R. M., \& Hunt, S. D. (1994). The commitmenttrust theory of relationship marketing. Journal of Marketing, 20-38.

- $\quad$ Nelson, R. R., \& Winter, S. G. (1982). An Evolutionary Theory of Economic Change. Cambridge: 1982.

- Nordstrom, K., \& Vahlne, J.-E. (1994). Is the Globe Shrinking? Psuchic Distance and the Establishemnt of Swedish Sales Subsidiaries During the Last 100 Years. In 
M. Landeck, International Trade: Regional and Global issue. United States: St. Martin's Press.

- O'Gray, S., \& Lane, H. (1996). The Psychic Distance Paradox. Journal of International Business Studies, 309333.

- $\quad$ Oviatt, B. M., \& McDougall, P. P. (1994). Toward a theory of international new ventures. Journal of International Business Studies.

- Panitchpakdi, S. (2008). Foreword. In K. P. Sauvant, The Rise of Transnational Corporations from Emerging Markets: Threat or Opportunity. Massachusetts: Edward Elgar.

- Peng, M. W., Wang, D. Y., \& Jiang, Y. (2008). An Institutional-based view of international business strategy: a Focus on emerging economies. Journal of International Business Studies, 920-936.

- Penrose, E. (1959). The Theory of the Growth of the Firm. Oxford: Brasil Blackwell.

- Prahalad, C. K. (2006). The fortune at the Bottom of the Pyramid. Philadelphia: Wharton School Publishing.

- Ramamurti, R. (2009). Why Study emerging-market multinationals? In R. Ramamurti, \& J. V. Singh, Emerging Multiantionals in Emerging Markets (pp. 322). New York: Cambridge University Press.

- Ramamurti, R. (2009a). What have we learned abourt emerging-market MNEs? In R. Ramamurti, \& J. Singh, Emerging Multinationals in Emerging Markets (pp. 399426). Cambridge: Cambridge University Press.

- Ramamurti, R. (2012). What is Really Different about Emerging Market Multinationals. Global Strategy Journal, pp. 41-47.

- Reuber, A. R., \& Fischer, E. (1997). The influence of teh management team's international experience on the internationalization behaviors of SMEs. Journal of International Business Behaviors of SMEs, 807-825.

- Rugman, A. (2010). Do we need a new theory to explain emerging markets? In K. Sauvant, W. Markets, \& G. McAllister, Foreign Direct Investments from Emerging Markets: The Challenge Ahead. New York: McMillan.

- Rugman, A., Verbeke, A., \& Nguyen, Q. (2011). Fifty Years of International Business Theory. Management International Review, 755-786.

- Sarasvathy, S. D. (2001). Causation and effectuation: Toward a Theoretical shift from economic inevitability to entrepreneurial contingency. Academy of Management Review, pp. 243-263.

- Teece, D. J. (2012). Dynamic capabilities: Routines versus entrepreneurial action. Journal of Management Studies, 395-1401.

- Teece, D. J., Pisano, G., \& Schuen, A. (1997). Dynamic capability and strategic management. Strategic Management Journal, 509-533.

- UNCTAD. (2015). World Investment Report 2015. New York: United Nations.
- Vahlne, J., \& Johanson, J. (2017). From internationalization to evolution: the Uppsala model at 40 years. JIBS, 48:1087.

- Vahlne, J.-E., \& Johanson, J. (2002). New technology, new business environments and new internationalization process? In V. Havila, M. Forsgren, \& H. Hakansson, Critical perspectives on internationalization (pp. 2009-228). London: Pergamon.

- Vahlne, J.-E., \& Johanson, J. (2013). The Uppsala Model on Evolution of the Multionational Business Enterprise From internalization to Coordination of Networks. Multinational Business Enterprise, 189-210.

- Vahlne, J.-E., \& Johanson, J. (2014). Replacing Tradicional Economics with Behavioral Assumptions in Constructing the Uppsala Model: Toward a Theory of the evolution of the Multinational Business Enterprise. Multidisciplinary Insights form New AIB Fellows, 159176.

- Vahlne, J.-E., \& Johanson, J. (2014). Replacing tradicional economics with behavioral assumptions in constructing the Uppsala Model: Towards a Theory on teh Evolution of the Multinational Business Enterprise (MBE). In Multidisciplinary Insights from New AIB Fellows. (pp. 159-176).

- Vahlne, J.-E., \& Widersheim-Paul, F. (1973). Economic Distance Model and Empirical Investigation. In J.-E. Vahlne, \& F. Widersheim-Paul, Export and Foreign Establishments. Uppsala: Department of Business Administration.

- Vahlne, J.-E., Ivarsson, I., \& Johanson, J. (2011). The tortuous road to globalization for Volvo's heavy truck business: Extending the Scope of the Uppsala Model. International Business Review, 1-14.

- Vahlne, J.-E., Schweizer, R., \& Johanson, J. (2012) Overcoming the Liability of Outsidership - The Challenge of $\mathrm{HQ}$ of the Global Firm. Journal of International Management, 224-232.

- Veron-Wortzel, H., Wortzel, L. H., \& Deng, S. (1988). Do Neophyte Exporters Understand Importers? Columbia Journal of World Business, 49-56.

- Wells, L. (1983). Third World Multinationals: The Rise of Foreign Investments from Developing Countries. Cambridge: MIT Press.

- Wiedersheim-Paul, F., Olson, H., \& Welch, L. S. (1978). Pre-exporting activity: the first step in internationalization. Journal of International Business Studies, 47-58.

- Williamson, J. (1966). Profit Growth and Sales Maximization. Economica.

- Williamson, P. J. (2015). The competitive advantages of emerging market multinationals: a re-assessment. Critical perspectives on international Business, 216235.

- Williamson, P. J., \& Zeng, M. (2009). Value-for-money strategies in recessionary times: lessons Western businessess must learn from emerging-market 
companies to suceed - at home and abroad. Harvard Business Review, 67-74.

- Winter, S. G. (2012). Purpose and progress in the theory of strategy: Comments on Gavetti. Organizational Science, 288-297.
- Zafarullah, M., Ali, M., \& Young, S. (1998). The internationalisation of the Small Firm in Developing Countries: Exploratory Research from Pakistan. Journal of Global Marketing, 21-40.

\section{ABOUT THE AUTHORS}

- Renan Henrique de Oliveira is a PhD Candidate at COPPEAD Federal University of Rio de Janeiro and obtained a Master Degree from Curtin University, Australia. He has national and international publications and has attended important conferences. E-mail: renan.oliveira@coppead.ufrj.br ORC: 0000-0001-7697-204X

- Ariane Roder Figueira is a PhD and Master in Political Science from USP focused on international relations. Bachelor's degree in Social Sciences from Universidade Estadual Paulista (UNESP). Professor in international business at the Federal University of Rio de Janeiro and coordinator of institutional relations at Coppead.E-mail: ariane.roder@coppead.ufrj.br

- Monica Pinhanez is Ph.D. in International Development and Public Policy from Massachusetts Institute Of Technology (MIT), Cambridge, Massachusetts. Master of Urban and Regional Planning from the Massachusetts Institute of Technology, Department of Urban Studies and Planning. Master's in public administration and Government from Fundação Getulio Vargas-SP. Bachelor in Law from the Pontifical Catholic University of São Paulo. E-mail: monica.pinhanez@fgv.br ORCID: 0000-0003-0815-9430 


\title{
Modelo de Uppsala: Uma teoria contingente para explicar o surgimento de EMNEs
}

\author{
Renan Henrique OliveiraA, Ariane Roder Figueira ${ }^{A}$ and Monica Pinhanez ${ }^{B}$ \\ ${ }^{A}$ Universidade Federal do Rio de Janeiro, UFRJ/COPPEAD, Rio de Janeiro, RJ, Brasil \\ ${ }^{B}$ INSPER Business School, São Paulo, SP, Brasil
}

\section{DETALHES DO ARTIGO}

\section{Histórico do Artigo:}

Recebido: 02 de Aagosto de 2017

Revisado: 10 de Fevereiro de 2018

Aceito: 07 de Abril de 2018

Disponível online em: 01 de Maio de 2018

Sistema de revisão "Double blind review"

Editor Científico

Ilan Avrichir

Palavras-chaves:

Modelo de Uppsala

Multinacionais de Mercados Emergentes (EMNEs)

Teoria da Contingência

\section{RESUMO}

\begin{abstract}
O modelo Uppsala é o resultado de uma jornada intelectual em que suposições econômicas foram expurgadas e substituídas por relações comportamentais, de rede, capacidades dinâmicas, efetivação, teorias empreendedoras e institucionais, teorias que pareciam explicar melhor, o processo de internacionalização no atual ambiente de negócios. Este artigo conceitual ilustra como o modelo de Uppsala evoluiu, mostrando as adaptações pelas quais passou e discute se o modelo de Uppsala é contingente o suficiente para explicar o surgimento de EMNEs, um fenômeno que inicialmente intrigou os especialistas em negócios internacionais e questionou a validade de fluxos bem estabelecidos de pensamentos na comunidade empresarial internacional.
\end{abstract}

C 2018 Internext | ESPM. Todos os direitos reservados!

To cite this article:

Oliveira, R. H., Figueira, A. R., and Pinhanez, M. (2018) Uppsala model: A contingent theory to explain the rise of EMNEs. Internext - Review of International Business, 13 (2), 30-42. DOI: http://dx.doi.org/10.18568/1980-4865.13230-42

For access this article: http://dx.doi.org/10.18568/1980-4865.13230-42 